\title{
Re-infection of the prion from the scrapie-infected cell line SMB-S15 in three strains of mice, CD1, C57BL/6 and Balb/c
}

\author{
KANG XIAO $^{1 *}$, BAO-YUN ZHANG $^{1 *}$, XIAO-MEI ZHANG $^{1}$, JING WANG $^{1}$, CAO $^{*}$ CHEN $^{1}$, \\ LI-NA CHEN ${ }^{1}$, YAN LV ${ }^{1}$, QI SHI ${ }^{1}$ and XIAO-PING DONG ${ }^{1,2}$ \\ ${ }^{1}$ State Key Laboratory for Infectious Disease Prevention and Control, Collaborative Innovation Center \\ for Diagnosis and Treatment of Infectious Diseases of Zhejiang University, National Institute for Viral Disease Control and \\ Prevention, Chinese Center for Disease Control and Prevention, Beijing 102206; ${ }^{2}$ Key Laboratory \\ of Pathogenic Microbiology and Immunology, Institute of Microbiology, \\ Chinese Academy of Sciences, Beijing 100101, P.R. China
}

Received June 23, 2015; Accepted December 23, 2015

DOI: $10.3892 / \mathrm{ijmm} .2016 .2465$

\begin{abstract}
It is well known that the SMB-S15 cell line was originally established by cultures from the brains of mice affected by the Chandler scrapie strain, and this cell line may express $\operatorname{PrP}^{\mathrm{Sc}}$ permanently. However, the infectivity of the S15-derived prions on experimental animals has not yet been well documented. In the present study, the cell lysates of SMB-S15 were intracerebrally inoculated into three different strains of mice, namely C57BL/6, Balb/c and CD1. Prion protein (PRNP) gene sequencing revealed the same encoded $\operatorname{Pr} P$ proteins in the sequences of amino acids in the three strains of mice, in addition to a synonymous single nucleotide polymorphism (SNP) in CD1 mice. All infected mice developed typical experimental transmissible spongiform encephalopathies (TSEs) approximately six months post-infection. The clinical features of three infected mice were comparable. The pathogenic characteristics, such as the electrophoretic and glycosylation profiles and proteinase $\mathrm{K}(\mathrm{PK})$ resistance of $\mathrm{PrP}^{\mathrm{Sc}}$ molecules, as well as the neuropathological characteristics, such as spongiform vacuolation, $\mathrm{PrP}^{\mathrm{Sc}}$ deposits in cortex regions, astrogliosis and activated microglia, were also similar in all three strains of infected mice. However, $\operatorname{PrP}^{\mathrm{Sc}}$ deposits in the cerebellums of CD1 mice were significantly fewer, which was linked with the observation that lower numbers of CD1 mice presented
\end{abstract}

Correspondence to: Professor Xiao-Ping Dong or Dr Qi Shi, State Key Laboratory for Infectious Disease Prevention and Control, Collaborative Innovation Center for Diagnosis and Treatment of Infectious Diseases of Zhejiang University, National Institute for Viral Disease Control and Prevention, Chinese Center for Disease Control and Prevention, 155 Chang-Bai Road, Beijing 102206, P.R. China

E-mail: dongxp238@sina.com

E-mail: shiqi76@126.com

*Contributed equally

Key words: scrapie, prion, SMB-S15 cells, mice, bioassay, neuropathology cerebellum-associated symptoms. Successive inoculation of the individual strains of mice with brain homogenates from the infected mice also induced typical experimental scrapie. The data in the present study thus confirm that the prion agent in SMB-S15 cells causes stable infectivity in different types of mice with distinct phenotypes after long-term propagation in vitro. The present study also provides further scrapie rodent models, which may be used in further studies.

\section{Introduction}

Prion diseases, also known as transmissible spongiform encephalopathies (TSEs), are a group of transmissible and rapidly progressive neurodegenerative diseases including Creutzfeldt-Jakob disease (CJD), fatal familial insomnia (FFI) in humans, bovine spongiform encephalopathy (BSE) in cattle, scrapie in sheep and chronic wasting disease (CWD) in cervids, that can affect a series of species in mammals (1). The key pathogens of prion diseases are thought to be prions, which are completely different from all known microorganisms since nucleic acids are not found in them (2,3). Prion proteins are found naturally in normal brains and certain other organs $(4,5)$. However, the accumulation of an alternative or abnormal isoform of prion protein known as $\operatorname{PrP}^{\mathrm{Sc}}$, which is partially resistant to the digestion of proteinase $\mathrm{K}(\mathrm{PK})$, leads to neurodegeneration. $\mathrm{PrP}^{\mathrm{Sc}}$ stimulates the conversion of normal prion protein $\left(\mathrm{PrP}^{\mathrm{C}}\right)$ into nascent $\operatorname{PrP}^{\mathrm{Sc}}(6,7)$. Both $\mathrm{PrP}^{\mathrm{Sc}}$ and its normal form, $\operatorname{PrP}^{\mathrm{C}}$, share identical amino acid sequences (8); the differences between the two proteins are in their secondary structure. Compared to $\operatorname{PrP}^{\mathrm{C}}, \operatorname{PrP}^{\mathrm{sc}}$ has a higher $\beta$-sheet and lower $\alpha$-helix content in terms of the PrP secondary structure $(9,10)$.

Generally, prions selectively replicate themselves in the central nervous system (CNS) $(11,12)$, where there are high levels of $\mathrm{PrP}^{\mathrm{C}}$ expression. Certain strains of prions can also propagate in peripheral tissues, such as the lymph tissue (13). Usually, it is extremely difficult to get prions to directly replicate themselves in cultured cells. Several cell lines, mostly neuron-derived cells, however, have been described as being able to host the replications of a few special prion strains, either 
temporally or continually in vitro $(14,15)$. The SMB-S15 cell line was originally established when it was cultured from the brain of a mouse affected by the Chandler scrapie strain (16). SMB-S15 cells help scrapie prions to replicate continuously in vitro and possess almost the same biochemical characteristics as the original $\mathrm{PrP}^{\mathrm{Sc}}$ in brain tissues. However, the effect of the infectivity of the cell culture-derived prions on experimental animals has not yet been well documented.

To address this lacuna in the research, the lysates of SMB-S15 cells were intracerebrally inoculated into three different strains of mice, namely C57BL/6, Balb/c and CD1. We found that typical experimental TSEs were induced in all challenged mice, and similar incubation times were noted. Although the major neuropathological abnormalities and biochemical features of brain $\operatorname{PrP}^{\mathrm{Sc}}$ were similar in all three strains of mice, the clinical manifestations and $\operatorname{PrP}^{\mathrm{Sc}}$ deposits in the cerebellum regions of the tested rodents exhibited certain differences.

\section{Materials and methods}

Cell culture. The cell line infected with the scrapie agent Chandler and its cured cell line SMB-PS were obtained from The Roslin Institute (Scotland, UK). SMB-S15 was originally taken from the brain of a mouse infected by the Chandler scrapie strain (17). SMB-PS denotes SMB cells which have been permanently cured by pentosan sulfate (PS) (16). Cells were cultured in DMEM with $10 \%$ fetal calf serum, in an atmosphere with $5 \% \mathrm{CO}_{2}$ and at $33^{\circ} \mathrm{C}$. Cells were collected, counted and stored at $-20^{\circ} \mathrm{C}$ for further study.

Animal bioassay. Approximately $1 \times 10^{8} \mathrm{SMB}-\mathrm{S} 15$ and SMB-PS cells were homogenized in $2 \mathrm{ml}$ phosphate-buffered saline (PBS; $\mathrm{pH}$ 7.4), respectively. We verified that the content of $\mathrm{PrP}^{\mathrm{Sc}}$ in the cell homogenates was comparable with that in ME7- or 139A-infected brain homogenates by western blot analysis (data not shown). Cell debris was removed with low-speed centrifugation at 2,000 x g for $10 \mathrm{~min}$, and the supernatants were collected as inoculums prior to challenging. Five microliters of SMB-S15 or SMB-PS cell homogenates were intracerebrally injected into 3 to 4-week-old CD1, C57BL/6 and Balb/c mice, respectively. Each of the 6 groups (the CD1, C57BL/6 and Balb/c mice injected with either SMB-S15 or SMB-PS) consisted of 10 female mice. Before the injection, all mice were narcotized with halothane. The animals were monitored twice a week before the appearance of clinical symptoms by experienced staff, but once per day after the appearance of clinical symptoms, until the animals died or were sacrificed. The clinical symptoms and signs were scored as previously described (18). The incubation time was calculated from the inoculation to the onset of clinical manifestations, and clinical course was evaluated from the onset of clinical manifestations to death at the terminal stage of the disease. The main clinical manifestations at the end of the disease included progressive ataxia, sluggishness, loss of weight and extreme emaciation. At the end of the clinical phase, the animals were sacrificed using ether and exsanguinated, and the brains were surgically removed from the mice. Three brains were fixed with formalin, and the others were stored at $-80^{\circ} \mathrm{C}$ for further analyses. In addition, two untreated 3 to 4 -week-old mice from each strain were sacrificed using ether, and $200 \mu \mathrm{l}$ blood was collected and anticoagulated with ethylenediaminetetraacetic acid (EDTA) for gene sequencing.

For successive passage, each brain from 3 SMB-S15inoculated strains and each from SMB-PS-inoculated strains were homogenized $(1: 10, \mathrm{w} / \mathrm{v})$. Before injection, western blot analysis indicated that the $3 \mathrm{~S} 15$-inoculated brains were positive for PrPSc, while the SMB-PS-inoculated brains were negative. One microliter of each brain homogenate was intracerebrally injected into corresponding 3 to 4-week-old CD1, C57BL/6 and $\mathrm{Balb} / \mathrm{c}$ mice. Each group consisted of 10 female mice. These mice were termed second passage SMB-inoculated mice.

Polymerase chain reaction (PCR) protocol for the prion protein (PRNP) gene. Total DNA was extracted from the blood of the mice (the 2 untreated mice from each strain) with a DNeasy Blood \& Tissue kit (cat. no. 69504; Qiagen, Hilden, Germany) according to the manufacturer's instructions. The mouse PRNP gene was amplified using PCR in a Bio-Rad S1000 Thermal Cycler (Bio-Rad, Hercules, CA, USA). Two pairs of primers were used for better accuracy. The information of the primers was as follows: pair 1 forward, TCAGCCT AAATACTGGGCAC and reverse, AGATGAGGAGGATG ACAGGA; and pair 2 forward, GCCTAAATACTGGGC ACTGATAC and reverse, AGGAGATGAGGAGGATGACA; the size of both amplicons was $791 \mathrm{bp}$. The reaction mixtures consisted of a total of $50 \mu \mathrm{l}$, containing $1 \mu \mathrm{l}$ DNA, $20 \mathrm{pmol}$ sense and antisense primers, $21 \mu \mathrm{l}$ RNase-free water and $25 \mu \mathrm{l}$ 2X Taq Master Mix (CW0682; CWBio, Beijing, China). The touchdown method was adopted to increase the specificity of the PCR products. Details of the PCR conditions are as follows: denaturing at $94^{\circ} \mathrm{C}$ for $40 \mathrm{sec}$, annealing at $59^{\circ} \mathrm{C}$ for $45 \mathrm{sec}$ with a decrease of $0.5^{\circ} \mathrm{C}$ every cycle in the first 8 cycles and $55^{\circ} \mathrm{C}$ for the other 30 cycles, and a final extension at $72^{\circ} \mathrm{C}$ for $55 \mathrm{sec}$. All PCR assays were carefully carried out in the PCR laboratory in four separate rooms to avoid DNA contamination.

Direct sequencing. The PCR products were analyzed in $1.2 \%$ agarose gel and recovered from gel with a QIAquick Gel Extraction kit (cat. no. 28706; Qiagen) according to the manufacturer's instructions. Direct sequencing was performed using the same PCR primers and an ABI Prism ${ }^{\mathrm{TM}}$ 3730XL DNA Analyzer.

Preparation of brain homogenates and PK digestion. The brain samples of the SMB-S15- and SMB-PS-inoculated mice were homogenized in $10 \%$ lysis buffer $(100 \mathrm{mM} \mathrm{NaCl}, 10 \mathrm{mM}$ EDTA, $0.5 \%$ Nonidet P-40, $0.5 \%$ sodium deoxycholate, and $10 \mathrm{mM}$ Tris, $\mathrm{pH}$ 7.5) according to a previously described protocol (19). Briefly, tissue debris was removed with low-speed centrifugation at $2,000 \mathrm{x}$ g for $10 \mathrm{~min}$, and the supernatants were collected. To detect the presence of PK-resistant $\mathrm{PrP}^{\mathrm{Sc}}$ in brain tissues, the brain homogenates were firstly digested with a final concentration of $50 \mu \mathrm{g} / \mathrm{ml} \mathrm{PK}$ at $37^{\circ} \mathrm{C}$ for $60 \mathrm{~min}$ prior to western blot analyses. To evaluate the PK resistances of $\mathrm{PrP}^{\mathrm{Sc}}$ from the three mouse strains, the brain homogenates of the SMB-S15-inoculated mice were treated with different amounts of PK (70663-4; Merck KGaA, Darmstadt, Germany) at final concentrations of 100, 200, 500, 1,000, 2,000 and $5,000 \mu \mathrm{g} / \mathrm{ml}$ at $37^{\circ} \mathrm{C}$ for $60 \mathrm{~min}$. PK digestion was terminated by heating the samples at $100^{\circ} \mathrm{C}$ for $10 \mathrm{~min}$. 
Western blot analysis. Aliquots of brain homogenates were separated on 15\% SDS-PAGE and electroblotted onto nitrocellulose membranes using a semi-dry blotting system (Bio-Rad). Membranes were blocked with $5 \%$ (w/v) non-fat milk powder (NFMP) in $1 \mathrm{X}$ Tris-buffered saline containing $0.1 \%$ Tween-20 (TBST) at room temperature for $1 \mathrm{~h}$ and probed with anti-PrP monoclonal antibody (mAb 6D11, sc-58581; Santa Cruz Biotechnology, Inc., Santa Cruz, CA, USA) at $4^{\circ} \mathrm{C}$ overnight. After washing with TBST, blots were incubated with horseradish peroxidase (HRP)-conjugated goat anti-mouse (cat. no. 31460; Thermo Fisher Scientific, Waltham, MA, USA) at room temperature for $2 \mathrm{~h}$. Blots were developed using an enhanced chemiluminescence system (ECL) (NEL103E001EA; PerkinElmer, Waltham, MA, USA) and visualized on autoradiography films. Images were captured by the ChemiDoc ${ }^{\mathrm{TM}} \mathrm{XRS}^{+}$ Imager (Bio-Rad).

Deglycosylation assay. After being mixed with equal volumes of glycoprotein denaturing buffer (New England Biolabs, Ipswich, MA, USA), various PK-treated brain homogenates were heated at $100^{\circ} \mathrm{C}$ for $10 \mathrm{~min}$. Subsequently, $50 \mathrm{mM}$ sodium phosphate, $\mathrm{pH} 7.5$, containing $1 \% \mathrm{NP}-40$ and $2 \mu \mathrm{l}$ N-glycosidase F (1,800,000 U/mg; New England Biolabs) were added to the samples, and the mixtures were incubated at $37^{\circ} \mathrm{C}$ for $2 \mathrm{~h}$. PrP signals in each preparation were detected by western blot analysis, as described above.

Pathological assays. Brain tissues of the differently inoculated mice were fixed in $10 \%$ buffered formalin solution. Before histological processing, all fixed tissues were immersed in $98 \%$ formic acid for at least $1 \mathrm{~h}$ for inactivation and paraffinembedded. The paraffin-embedded sections (5 $\mu \mathrm{m}$ thickness) were then subjected to conventional staining with hematoxylin and eosin (H\&E). The spongiform degeneration in the brain regions infected with various scrapie strains was monitored using a light microscope (BX41; Olympus, Tokyo, Japan), and the severity and distribution of vacuolation were measured according to previously described protocol (20). Briefly, 0 denotes no lesions; 0.5 , minimum vacuolation (2-3 vacuoles in half an $\mathrm{x} 40$ objective field); 1.0, little vacuolation (3-5 vacuoles in half a field); 2.0, moderate vacuolation (several vacuoles evenly scattered); 3.0, extensive vacuolation (many vacuoles distributed in half a field); and 4.0, severe vacuolation (numerous vacuoles, often coalescing).

Immunohistochemical (IHC) assays. Paraffin-embedded sections ( $5 \mu \mathrm{m}$ thickness) of brain tissues were prepared, and IHC assays were performed according to protocol described in a previous study (18). Prior to the staining with $\operatorname{PrP} \mathrm{mAb}$, brain sections were treated with $6 \mathrm{M} \mathrm{GdnHCl}$ at $4^{\circ} \mathrm{C}$ for $2 \mathrm{~h}$. In sections, endogenous peroxidases were quenched in $3 \% \mathrm{H}_{2} \mathrm{O}_{2}$ in methanol for $15 \mathrm{~min}$, and then sections were pretreated for enzyme digestion antigen retrieval for $1 \mathrm{~min}$. After blocking in $1 \%$ normal goat serum, the sections were incubated at $4^{\circ} \mathrm{C}$ overnight with anti-PrP mAb (6D11), rabbit anti-glial fibrillary acidic protein (GFAP) polyclonal antibody (pAb; Boster Biological Tech Ltd.) or rabbit anti-Iba1 pAb, respectively. The sections were then incubated with HRP-conjugated goat anti-mouse or rabbit secondary antibody (cat nos. 31460 and 31430; Thermo Fisher Scientific) at $37^{\circ} \mathrm{C}$ for $60 \mathrm{~min}$, and visualized by incubation with 3,3-diaminobenzidine tetrahydrochloride (DAB). The sections were counterstained with hematoxylin, dehydrated and mounted in permount (ZLI-9559, ZSGB-BIO, Beijing, China).

Statistical analysis. Statistical analysis was performed using SPSS 17.0 statistical package (SPSS, Inc., Chicago, IL, USA). Quantitative analysis of the western blots was carried out using ImageJ software. The gray values of each target blot were evaluated. Statistical analyses were performed using the Kruskal-Wallis test and Student's t-test, as appropriate. A P-value $<0.05$ was considered to indicate a statistically significant difference.

Ethical statement. The present study was approved by the Ethical Committee of the National Institute for Viral Disease Control and Prevention, China (CDC) under protocol no. 2009ZX10004-101.

\section{Results}

Homogeneity of the PRNP gene in three different strains of mice. C57BL/6, CD1 and Balb/c mice are commonly used experimental mice strains with clearly distinct phenotypes. In order to study the homogeneity of the PRNP gene in the three different types of mice, genomic DNA was extracted from peripheral blood cells, and the PRNP genes were obtained using a specific PCR technique. Sequencing assays of the 791-bp PCR products revealed $100 \%$ homogeneity between the C57BL/6 and $\mathrm{Balb} / \mathrm{c}$ mice, which were also identical to the mouse PRNP sequences found on NCBI (CT010345.1), whereas only one different nucleotide at the position of nt 564 (C-T exchange) in CD1 mice was noted (Fig. 1A). According to the codon table, it was confirmed that this C564T variation in CD1 mice was a synonymous single nucleotide polymorphism (SNP) which did not cause any change of the encoded amino acid (valine). The polymorphisms of codon 128 of PrP proteins of those three strains of mice, which corresponded to the polymorphism of codon 129 in humans, were all methionine/methionine (Met/Met) homozygote (Fig. 1B). These data indicate a homogeneity in the PRNP gene among the three strains of mice.

Inoculation of SMB-S15 cell lysates into CD1, Balb/c, and C57BL/6 mice induced experimental TSEs. Cell lysates of SMB-S15 with detectable PK-resistant $\mathrm{PrP}^{\mathrm{Sc}}$ were intracerebrally inoculated into $10 \mathrm{CD} 1, \mathrm{Balb} / \mathrm{c}$ and C57BL/6 mice, respectively, and cell lysates of SMB-PS without detectable $\mathrm{PrP}^{\mathrm{Sc}}$ were also intracerebrally inoculated into the mice of each strain as controls. One mouse in each SMB-S15inoculated group died within a week of inoculation, and we considered this to be due to the acute mechanical brain damage suffered during inoculation. Animals infected with SMB-S15 lysates began to exhibit abnormal signs 165 days after inoculation, and the onset times of diseases within the groups, or among the different strains, were quite similar. The average incubation times of CD1, Balb/c and C57BL/6 mice were $175.4 \pm 1.0,175.3 \pm 1.2$ and $172.8 \pm 1.8$ days, respectively, and no statistical difference was noted $(\mathrm{P}=0.382)$ (Table I). Severe weight loss, extreme emaciation and sluggishness were observed in all infected animals. Compared with the 
Table I. Clinical characteristics and brain $\mathrm{PrP}^{\mathrm{Sc}}$ deposits of SMB-S15-inoculated C57BL/6, CD1 and Balb/c mice.

\begin{tabular}{|c|c|c|c|c|c|c|c|c|}
\hline \multirow[b]{2}{*}{ Mice } & \multirow{2}{*}{$\begin{array}{c}\text { No. of } \\
\text { ill/inoculated } \\
\text { mice }\end{array}$} & \multirow{2}{*}{$\begin{array}{l}\text { Incubation time } \\
\text { (means } \pm \text { SE) } \\
\text { (days) }\end{array}$} & \multirow{2}{*}{$\begin{array}{c}\text { Clinical course } \\
\text { (means } \pm \text { SD) } \\
\text { (days) }\end{array}$} & \multicolumn{4}{|c|}{$\begin{array}{l}\text { Major clinical manifestations/ } \\
\text { No. of positive/inoculated mice }\end{array}$} & \multirow{2}{*}{$\begin{array}{c}\text { No. of } \mathrm{PrP}^{\mathrm{Sc}} \\
\text { positive/inoculated } \\
\text { mice }\end{array}$} \\
\hline & & & & $\begin{array}{l}\text { Weight } \\
\text { loss }\end{array}$ & Ataxia & $\begin{array}{l}\text { Sluggish- } \\
\text { ness }\end{array}$ & Trembling & \\
\hline $\mathrm{C} 57 \mathrm{BL} / 6$ & $9 / 9$ & $165-180(172.8 \pm 1.8)$ & $7-24(12.7 \pm 6.6)$ & $9 / 9$ & $7 / 9$ & $8 / 9$ & $3 / 9$ & $9 / 9$ \\
\hline $\mathrm{Balb} / \mathrm{c}$ & $9 / 9$ & $173-180(175.3 \pm 1.2)$ & $7-17(11.4 \pm 4.6)$ & $9 / 9$ & $7 / 9$ & $7 / 9$ & $2 / 9$ & $9 / 9$ \\
\hline CD1 & $9 / 9$ & $173-180(175.4 \pm 1.0)$ & $7-20(11.9 \pm 5.1)$ & $9 / 9$ & $4 / 9$ & $7 / 9$ & $0 / 9$ & 9/9 \\
\hline
\end{tabular}

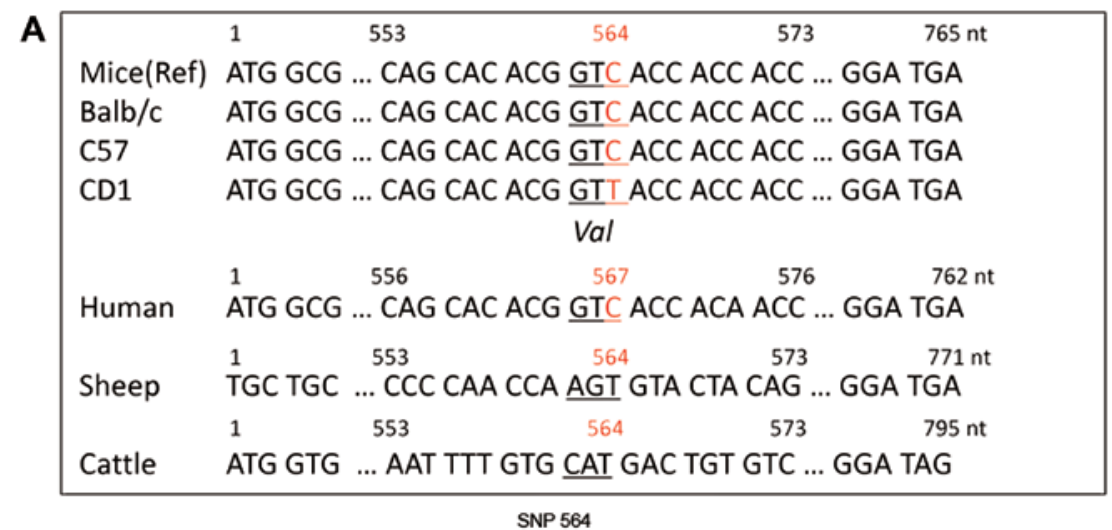

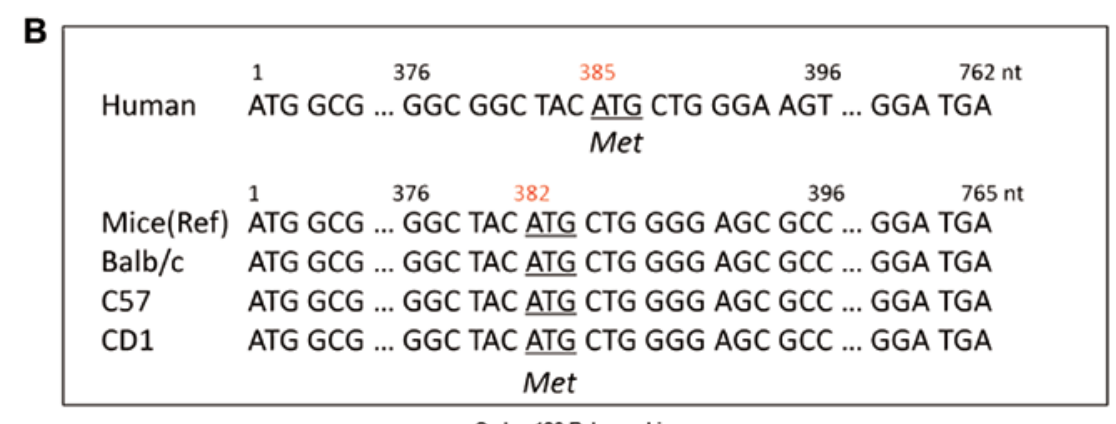

Figure 1. Prion protein gene (PRNP) sequencing of Balb/C, C57BL/6 and CD1 mice. (A) Comparison of the PRNP sequences of Balb/C, C57BL/6 and CD1 mice, referring to the sequences of mouse (CT010345.1), human (DQ408531.1), sheep (AB060288.1) and cattle (AY720678.1), as issued on GenBank. CD1 mouse contains a synonymous single nucleotide polymorphism (SNP). (B) Comparison of the polymorphism of codon 128 in Balb/C, C57BL/6 and CD1 mice, referring to the sequences of mouse and human.

individual SMB-PS-inoculated mice at the same survival time, SMB-S15-inoculated mice were of obviously lower weight. The average weight (in $95 \% \mathrm{CI}$ ) of the S15-infected $\mathrm{CD} 1, \mathrm{Balb} / \mathrm{c}$ and $\mathrm{C} 57 \mathrm{BL} / 6$ mice dropped down to 76, 85 and $84 \%$, respectively, thus exhibiting significant differences (see Table I and Fig. 2A). Ataxia (such as moving unsteadily with uncoordinated movements) was easily identified in the $\mathrm{S} 15$-inoculated C57BL/6 and Balb/c mice, but less frequently in CD1 mice. A small proportion of C57BL/6 and Balb/c mice, but not CD1 mice, trembled (Table I). The clinical manifestations progressed so quickly that almost all S15-treated mice died within 7-20 days after the onset of symptoms. The average clinical courses of S15-inoculated mice were 11.9 \pm 5.1 (CD1),

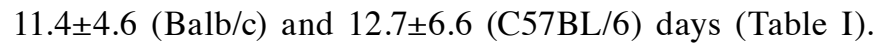
The survival times of the $\mathrm{S} 15$-inoculated mice were $187.3 \pm 2.5(\mathrm{CD} 1), 186.8 \pm 2.6(\mathrm{Balb} / \mathrm{c})$ and 185.4 $\pm 3.4(\mathrm{C} 57 \mathrm{BL} / 6)$ days, respectively (Fig. 2B). Animals inoculated with
SMB-PS lysates did not show any abnormality until the end of observation ( $>250$ days after inoculation).

Successive inoculation of brain homogenates of SMB-S15infected mice into various types of mice. In order to successively passage the scrapie agents from the brains of SMB-S15-infected mice (first passage) onto the same strain of mice, $10 \%$ brain homogenates with detectable PK-resistant $\mathrm{PrP}^{\mathrm{Sc}}$ were intracerebrally inoculated into ten CD1, Balb/c and C57BL/6 mice, respectively. Brain homogenates of SMB-PS-inoculated mice without detectable $\mathrm{PrP}^{\mathrm{Sc}}$ were also intracerebrally inoculated into the mice of each strain as controls. Two mice from the groups of C57BL/6 and Balb/c died within a week of inoculation, which was attributed to acute mechanical brain damage. The mice of second passage showed abnormal signs 140 days after inoculation. The clinical manifestations of the second passage S15-inoculated mice were almost the same as 
Table II. Clinical characteristics and brain $\mathrm{PrP}^{\mathrm{Sc}}$ deposits of second passage of SMB-S15-inoculated C57BL/6, CD1 and Balb/c mice.

\begin{tabular}{|c|c|c|c|c|c|c|c|c|}
\hline \multirow[b]{2}{*}{ Mice } & \multirow{2}{*}{$\begin{array}{c}\text { No. of } \\
\text { ill/inoculated } \\
\text { mice }\end{array}$} & \multirow{2}{*}{$\begin{array}{l}\text { Incubation time } \\
\text { (means } \pm \mathrm{SE}) \\
\quad(\text { days })\end{array}$} & \multirow{2}{*}{$\begin{array}{l}\text { Clinical course } \\
\text { (means } \pm \mathrm{SD}) \\
(\text { days })\end{array}$} & \multicolumn{4}{|c|}{$\begin{array}{l}\text { Major clinical manifestations/ } \\
\text { No. of positive/inoculated mice }\end{array}$} & \multirow{2}{*}{$\begin{array}{c}\text { No. of } \mathrm{PrP}^{\mathrm{Sc}} \\
\text { positive/inoculated } \\
\text { mice }\end{array}$} \\
\hline & & & & $\begin{array}{c}\text { Weight } \\
\text { loss }\end{array}$ & Ataxia & $\begin{array}{l}\text { Sluggish- } \\
\text { ness }\end{array}$ & Trembling & \\
\hline C57BL/6 & $8 / 8$ & $146-160(153.0 \pm 2.2)$ & $12-20(14.0 \pm 3.2)$ & $8 / 8$ & $8 / 8$ & $8 / 9$ & $2 / 8$ & $8 / 8$ \\
\hline $\mathrm{Balb} / \mathrm{c}$ & $8 / 8$ & $140-152(146.8 \pm 1.8)$ & $14-20(16.8 \pm 3.0)$ & $8 / 8$ & $7 / 8$ & $7 / 8$ & $1 / 8$ & $8 / 8$ \\
\hline CD1 & $10 / 10$ & $140-160(148.0 \pm 2.3)$ & $6-20(10.9 \pm 4.2)$ & $10 / 10$ & $8 / 10$ & $8 / 10$ & $1 / 10$ & $10 / 10$ \\
\hline
\end{tabular}

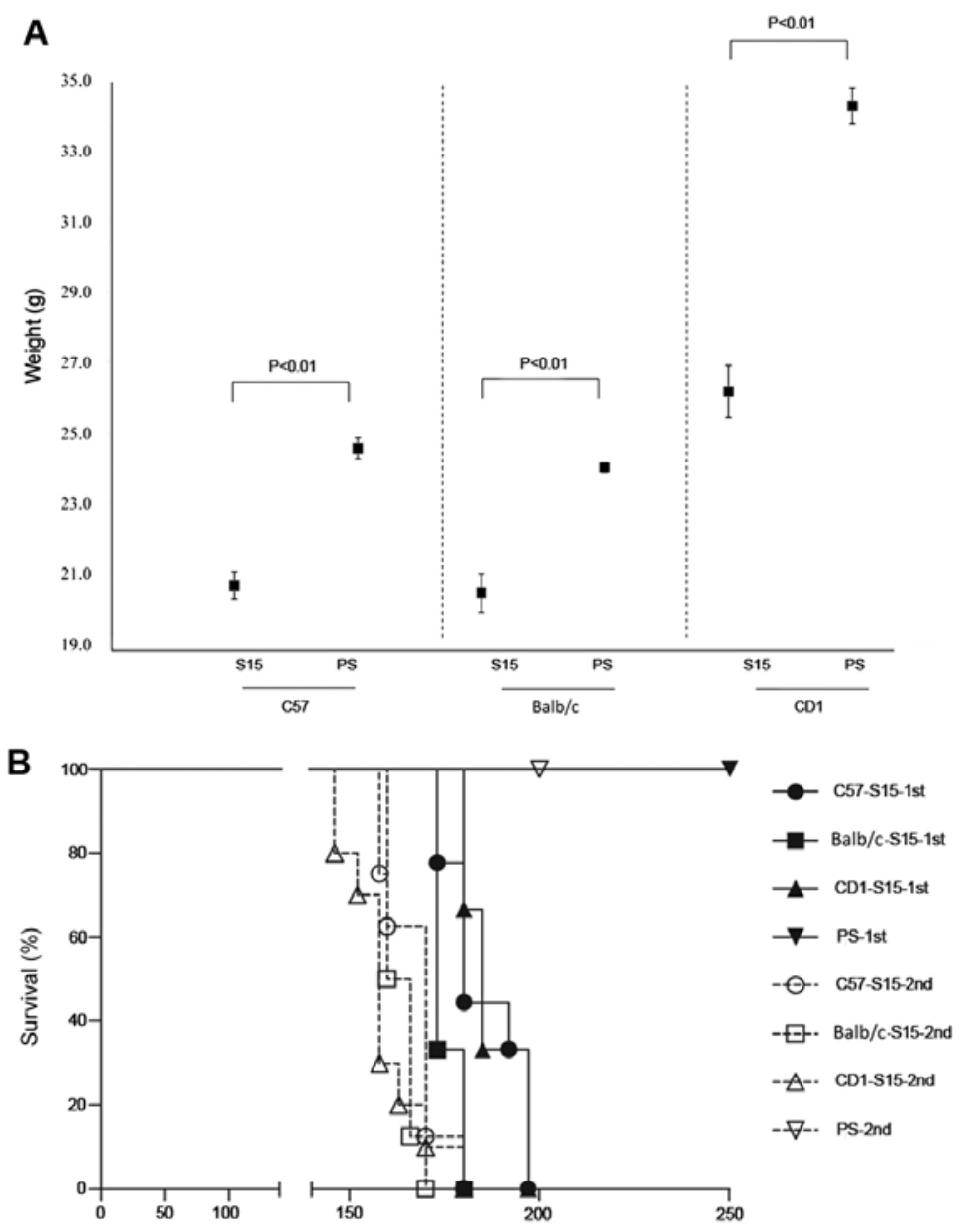

Figure 2. Body weight and survival times of the SMB-S15 (S15) and SMB-PS (PS) inoculated mice. (A) Body weight at the final stages of disease. The average body weight $(\mathrm{g})$ of the mice in each group are shown in the $\mathrm{y}$-axis, and data is represented as the means \pm SD. The statistical differences between S15- and PS-inoculated mice in each group are indicated above. (B) Survival times. Abscissa shows the survival times (days) and y-axis shows the survival (\%). PS, pentosan sulfate.

those of the first passage animals: among them, loss of body weight, ataxia and sluggishness were the most noticeable signs. The average incubation times of the second-passage S15-inoculated CD1, Balb/c and C57BL/6 mice were 148.0 \pm 2.3 , $146.8 \pm 1.8$ and $153.0 \pm 2.2$ days, respectively, and no statistical difference between the three strains of mice was noted $(\mathrm{P}=0.166)$ (Table II). However, compared with those of first passage mice, all second passage mice exhibited significantly shorter incubation times. The average clinical courses of second passage mice were 10.9 $\pm 4.2(\mathrm{CD} 1), 16.8 \pm 3.0(\mathrm{Balb} / \mathrm{c})$ and $14.0 \pm 3.2(\mathrm{C} 57 \mathrm{BL} / 6)$ days, respectively. The survival times of the second passage mice were significantly shorter than those of the first passage mice: $158.9 \pm 3.3(\mathrm{CD} 1, \mathrm{P}<0.001)$,

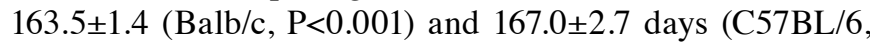
$\mathrm{P}=0.001$ ), respectively (Fig. 2B). Moreover, no abnormality was noted in PS-inoculated animals until the end of observation (>200 days after inoculation).

Presence of PK-resistant PrPS in the brain tissues of S15-inoculatedmice. To assess the presence of $\mathrm{PrP}^{\mathrm{Sc}}$ in the brains 


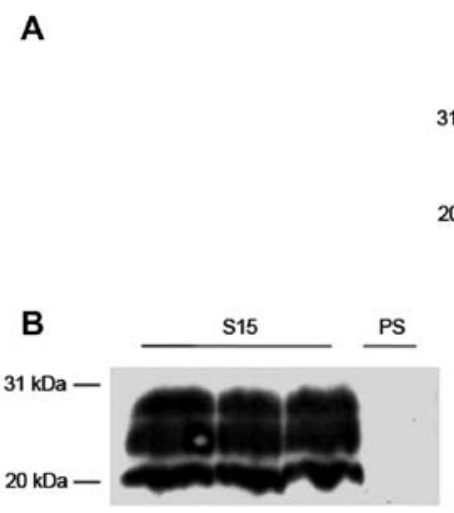

C57

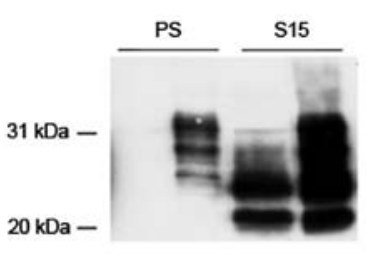

$\mathrm{PK}+-+$

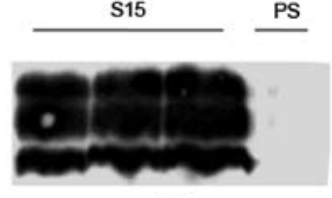

$\mathrm{CD} 1$
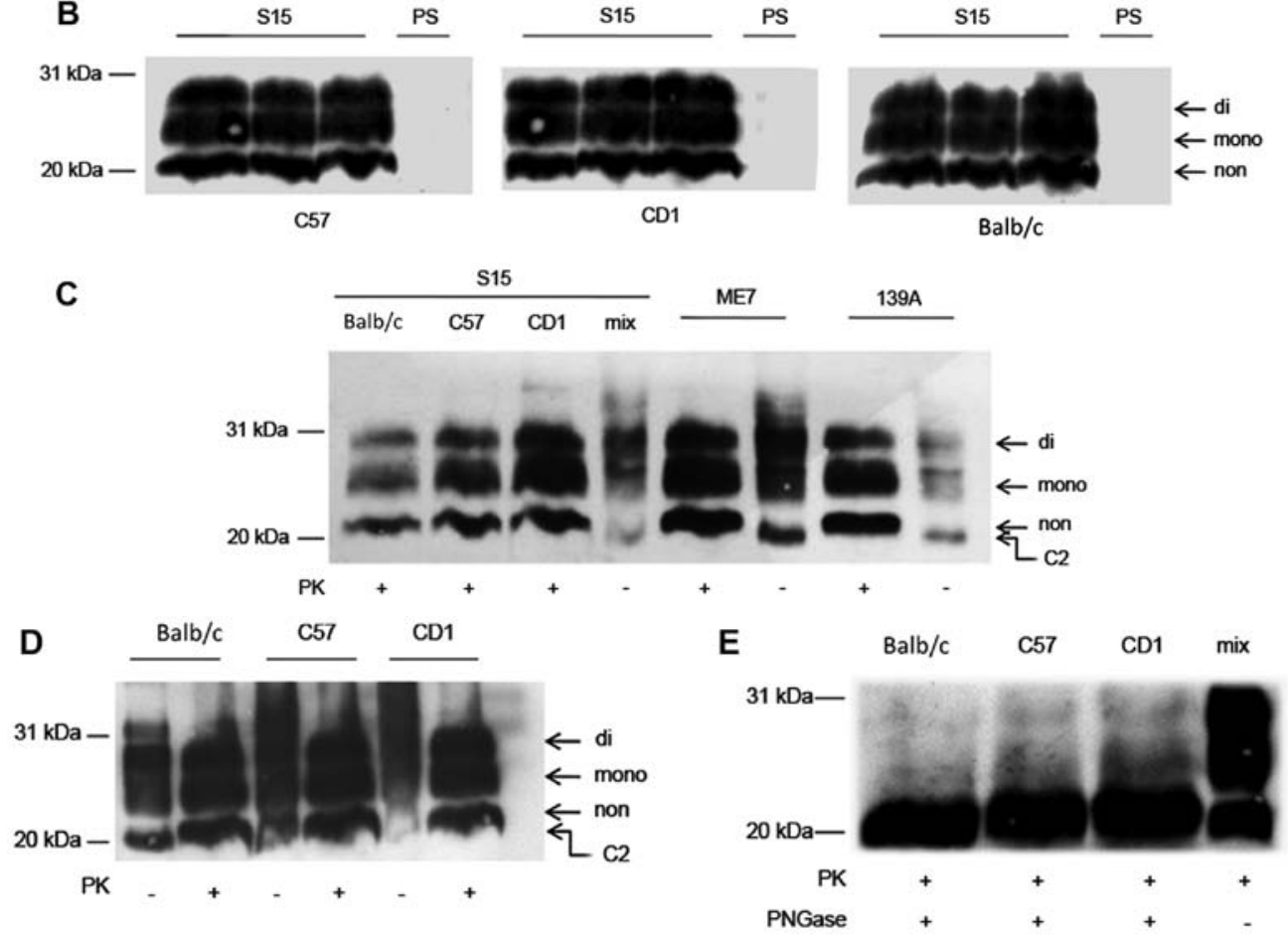

$\mathbf{F}$

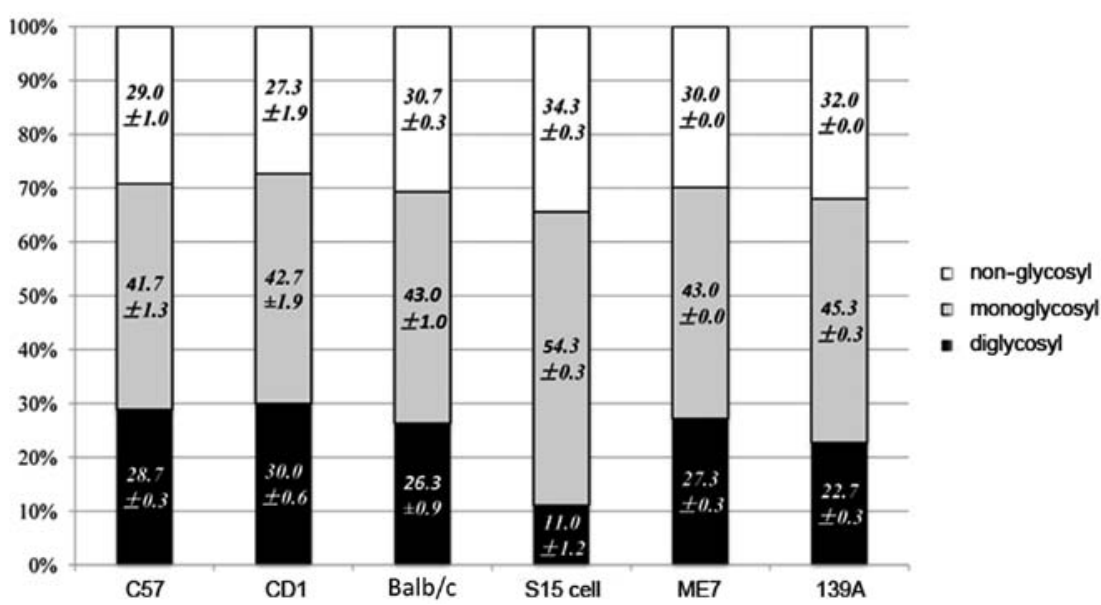

Figure 3. Western blot analysis for $\mathrm{PrP}^{\mathrm{Sc}}$ in the brain homogenates of SMB-inoculated mice. PrP-specific mAb 6D11 was used as the primary antibody. (A) Total $\operatorname{PrP}(\mathrm{PK}-)$ and $\mathrm{PrP}^{\mathrm{Sc}}(\mathrm{PK}+)$ in the lysates of SMB-S15- and SMB-PS-inoculated mice. (B) PrP ${ }^{\mathrm{Sc}}$ (PK+) in the brains of SMB-S15- and SMB-PS-inoculated Balb/C, C57BL/6 and CD1 mice. (C) C2 fragments and di-, mono- and un-glycosylated PrPsc in the brains of three SMB-S15 infected mice, as well as 139A- and ME7-infected mice. Mix represents the mixed brain homogenates of three SMB-S15-infected mice. (D) Total PrP (PK-) and PrPsc (PK+) in the brains of three SMB-S15 infected mice. (E) Deglycosylation of $\mathrm{PrP}^{\mathrm{Sc}}$ in the brains of three SMB-S15-infected mice. (F) Quantitative assays of the ratios of di-, mono- and un-glycosylated $\mathrm{PrP}^{\mathrm{Sc}}$ in the brains of mice treated with various experimental scrapie strains. The molecular markers are shown on the left. C57, CD1 and Balb/c refer to the homogenates of brains of mice inoculated with SMB-S15. S15 refers to the cell homogenates of SMB-S15 cells. PK, proteinase K.

of S15-inoculated mice, the brain homogenates of all diseased animals of the first passage were subjected to PK digestion and subsequently to western blot analysis with PrP-specific mAb 6D11. As with the SMB cell lysates (Fig. 3A), PK-resistant PrP signals were detected in the brain homogenates of all diseased mice of three different strains (Table I), which presented three predominant bands and migrated from 21-27 kDa (Fig. 3B). On the contrary, no trace of PK-resistant PrP signal was observed in the brain tissues of SMB-PS inoculated mice, regardless of whether they were CD1, Balb/c or C57BL/6 mice. 

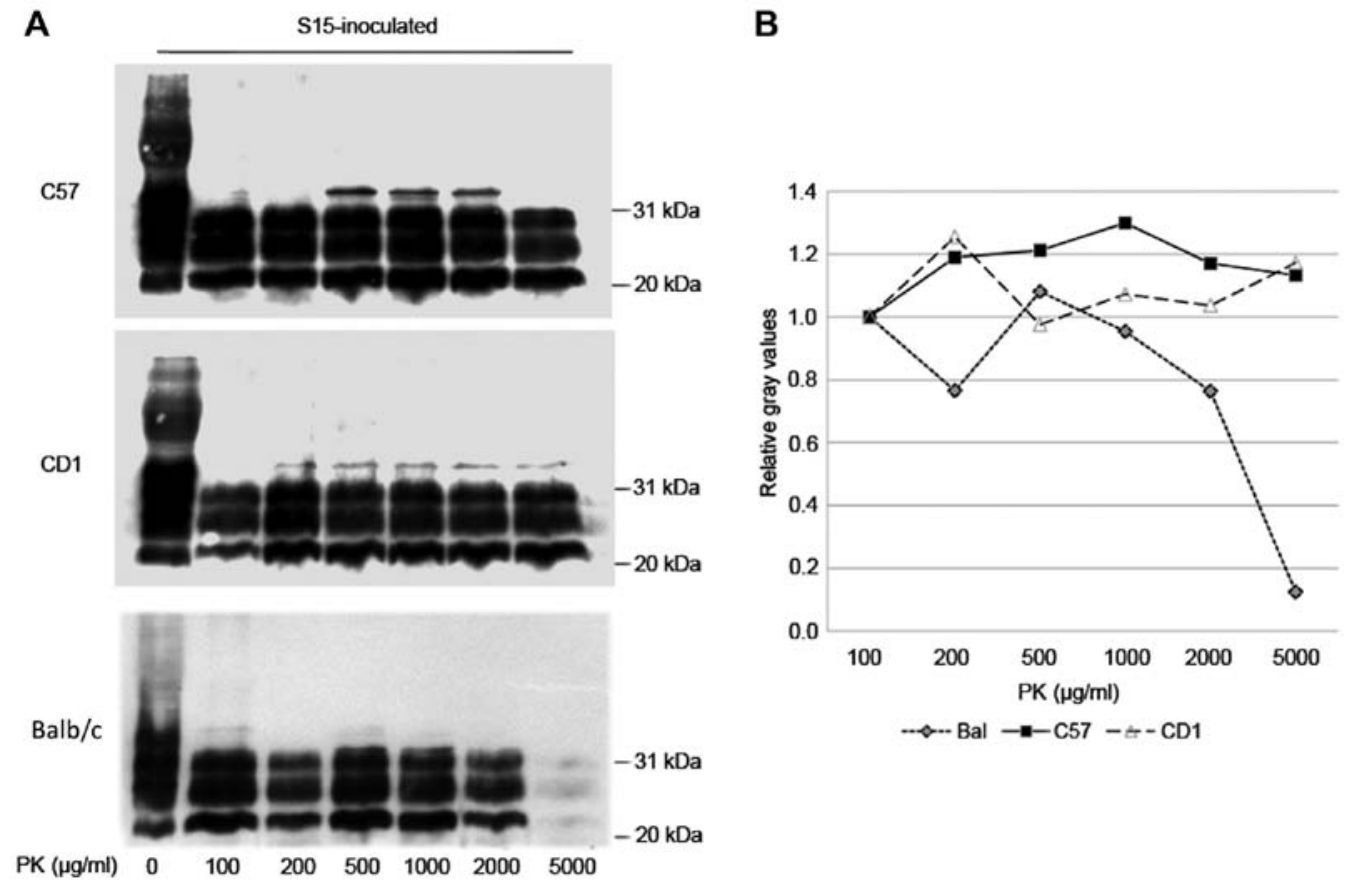

Figure 4. Assays of PK (proteinase K)-resistance of brains $\mathrm{PrP}^{\mathrm{Sc}}$ in three strains of SMB-S15 infected mice. (A) Western blots with mAb 6D11. The concentrations of PK in the individual preparation are indicated at the bottom. Different strains of mice are indicated on the left. (B) Quantitative analyses of each gray numerical value of PrP blots. Relative gray values of the PrP signals in each experiment are normalized to that of the respective reaction without PK.

To address the similarity in electrophoresis and glycosylation of $\mathrm{PrP}^{\mathrm{Sc}}$ molecules in the brains of the strains of mice inoculated with SMB-S15 cell lysates, the PK-treated and PK-untreated brain homogenates of the three different types of mice were separated on one SDS-PAGE together with those of scrapie strains 139A- and ME7-infected C57BL/6 mice and evaluated by PrP-specific western blot analysis. A band of roughly $21-\mathrm{kDa}$ was observed in all preparations of S15-inoculated mice that had not been treated with PK, which was located in the same location as those of 139A- and ME7-infected mice (Fig. 3C and D), possibly indicating that the same size $\mathrm{C} 2$ fragments of $\mathrm{PrP}$ were generated in brains infected with those three scrapie strains. Three PK-resistant PrP bands in three strains of S15-inoculated mice mobilized at the same positions as those in 139A- and ME7-infected mice, in which the monoglycosyl PrP ${ }^{\mathrm{Sc}}$ was the predominant form, followed by non-glycosyl and diglycosyl $\operatorname{PrP}^{\mathrm{Sc}}$ (Fig. 3C and D). Further deglycosylation of the $\operatorname{PrP}^{\mathrm{Sc}}$ molecules in the brains of S15-inoculated C57BL/6, CD1, $\mathrm{Balb} / \mathrm{c}$ mice with PNGase F revealed a signal PrP-specific band that was located in the same positions (Fig. 3E).

Calculating the relative gray values of each glycosyl $\mathrm{PrP}^{\mathrm{Sc}}$ band in the western blots showed that the percentages of di-, mono- and non-glycosyl forms in the brains of three S15-inoculated mice were 29,42 and $29 \%$ in C57BL/6; 30 , 43 and 27\% in CD1; and 26, 43 and 31\% in Balb/c mice. Compared with the glycosylating distributions of $\mathrm{PrP}^{\mathrm{Sc}}$ molecules in 139A-infected mice (23, 45 and 32\%) and ME7-infected mice $(27,43$ and $30 \%)$. No significant differences were noted between the three strains of S15-inoculated mice or between the mice infected with 139A, ME7 and S15 (Fig. 3F).

$\operatorname{Pr} P^{S c}$ molecules in the brain tissues of SMB-S15-infected mice possess strong $P K$-resistance. To compare the potential differ- ences in the levels of PK resistance of $\mathrm{PrP}^{\mathrm{Sc}}$ in the brains of SMB-15-inoculated C57BL/6, CD1 and Balb/c mice, the brain homogenates from 3 randomly selected mice of first passage were selected from each group and pooled as the representative samples. The samples were exposed to digestion with different amounts of PK, ranging from 100-5,000 $\mu \mathrm{g} / \mathrm{ml}$. Western blot analysis revealed clear and similar PK-resistant PrP signals in all three types of mice in the preparations treated with a low concentration of PK (from 100-2,000 $\mu \mathrm{g} / \mathrm{ml}$ ). However, as the concentration of PK increased to 5,000 $\mu \mathrm{g} / \mathrm{ml}$, the $\mathrm{PrP}^{\mathrm{Sc}}$ signals in Balb/c mice clearly became weaker, whereas $\mathrm{PrP}^{\mathrm{Sc}}$ in the other two strains of mice remained almost unchanged (Fig. 4). These results indicate the strong $\mathrm{PK}$ resistance of $\mathrm{PrP}^{\mathrm{Sc}}$ in the brains of S15-inoculated mice. The $\mathrm{PrP}^{\mathrm{Sc}}$ formed in the infected Balb/c mice seems to have slightly weaker PK-resistant properties than $\mathrm{PrP}^{\mathrm{Sc}}$ in $\mathrm{C} 57 \mathrm{BL} / 6$ and $\mathrm{CD} 1$ mice.

Large quantities of $\mathrm{PrP}^{S c}$ are deposited in the brains of the infected mice. In order to examine the characteristics of $\mathrm{PrP}^{\mathrm{Sc}}$ deposits in the brains of mice infected with SMB-S15, brain sections from SMB-S15-inoculated mice of the first passage were analyzed by $\mathrm{PrP}^{\mathrm{Sc}}$-specific IHC assays. After treatment with $\mathrm{GdnHCl}$, large amounts of brown $\operatorname{PrP}^{\mathrm{Sc}}$ deposits were detected in the cortex regions of S15-inoculated C57BL/6, CD1 and Balb/c mice, accompanied by various sizes of vacuoles, whereas no $\mathrm{PrP}^{\mathrm{Sc}}$ signal was observed in the cortex tissues of SMB-PS inoculated mice (Fig. 5). $\mathrm{PrP}^{\mathrm{Sc}}$ in the S15-infected mice mainly appeared in a dispersed manner.In the regions with more vacuoles, $\operatorname{PrP}^{\mathrm{Sc}}$ accumulated and formed relatively darkstained particles around the vacuoles. Three S15-inoculated mice presented quite similar $\mathrm{PrP}^{\mathrm{Sc}}$ deposit features in the cortex, regardless of the signal intensity or accumulating type. Obvious $\mathrm{PrP}^{\mathrm{Sc}}$ signals were also observed in the cerebellum regions of 


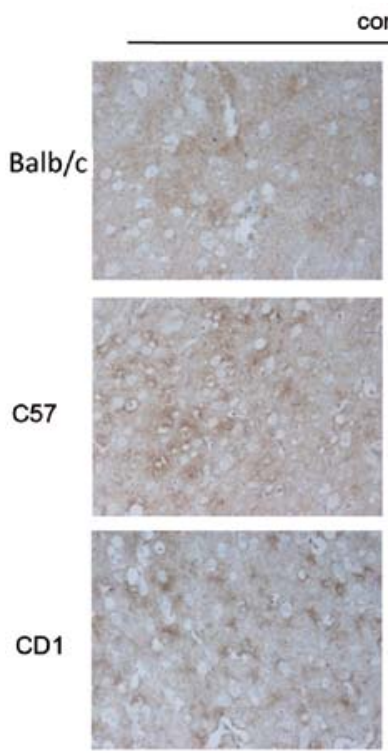

S15 cortex
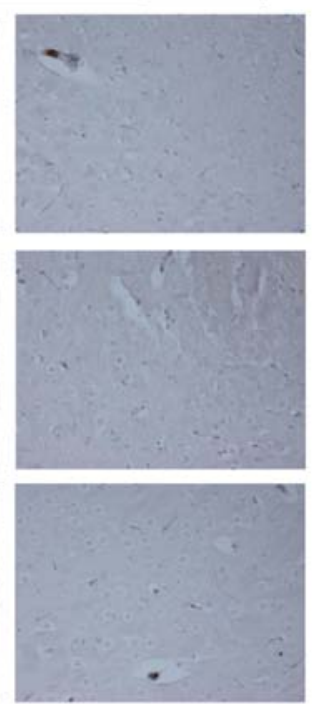

PS
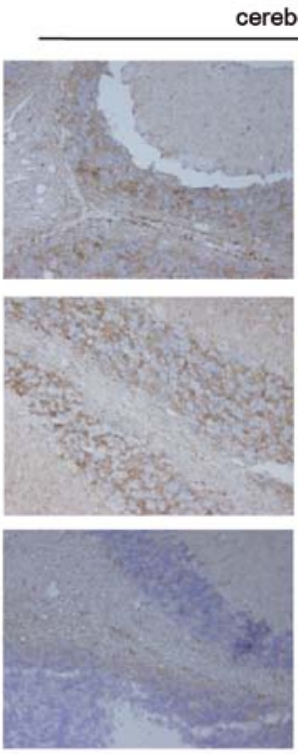

S15 cerebellum
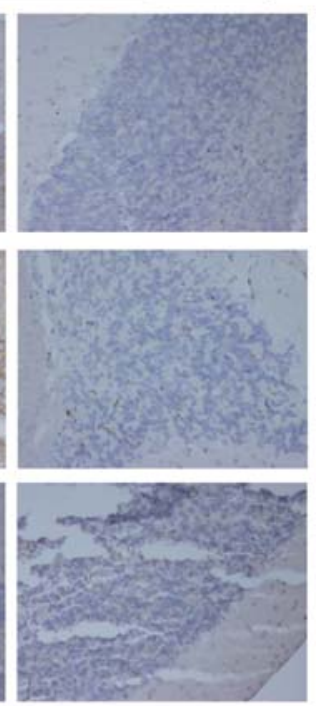

PS

PrPSc

$\times 40$

Figure 5. Immunohistochemical (IHC) assays for PrP ${ }^{\mathrm{Sc}}$ deposits in the brains of SMB-inoculated mice with mAb 6D11. Brain sections were treated with $\mathrm{GdnHCl}$ prior to reacting with mAb 6D11. Left panels, cortex; right panels, cerebellum; magnification, $\mathrm{x} 40$. Different strains of mice are indicated on the left.
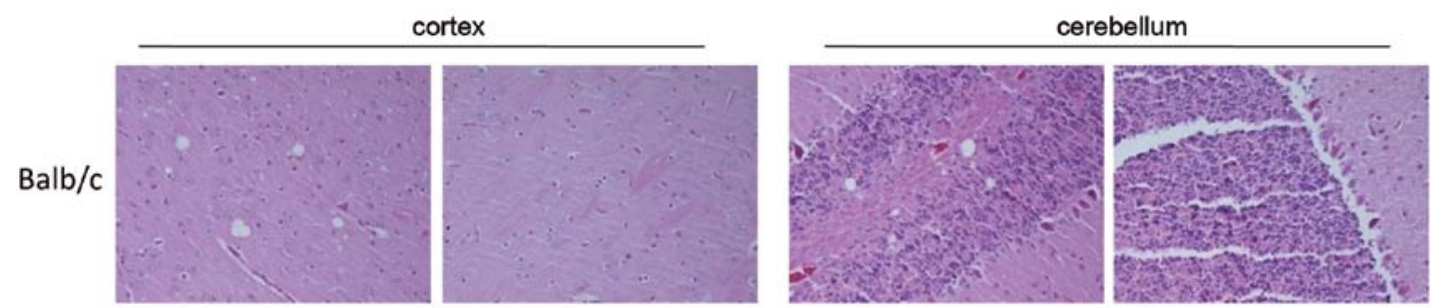

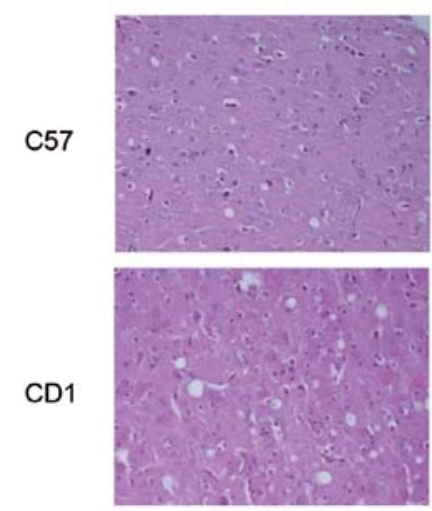

S15
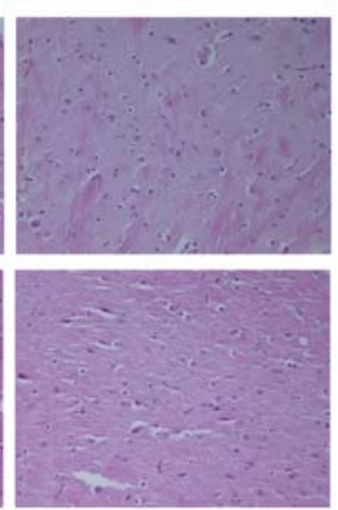

PS
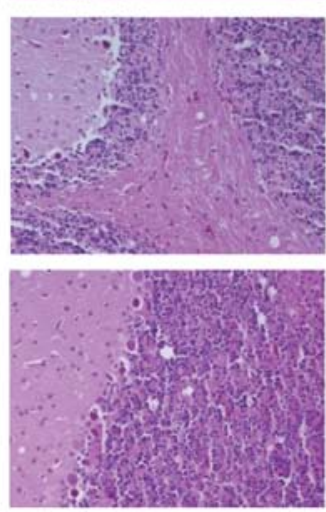

S15
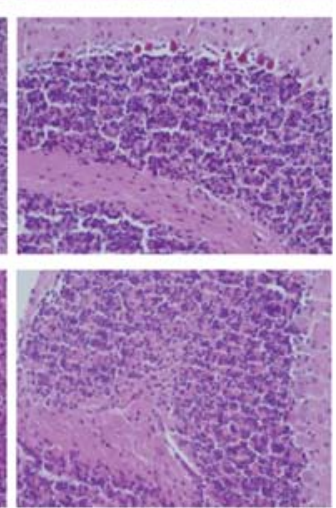

PS

H\&E

$\mathrm{x} 40$

Figure 6. H\&E staining of the brains of SMB-inoculated mice. Left panels, cortex; right panels, cerebellum; magnification, x40. Different strains of mice are indicated on the left.

S15-inoculated mice, which presented as numerous granular structures on a background of dispersive deposits, particularly in the regions of the gray layer. Noticeably, the $\mathrm{PrP}^{\mathrm{Sc}}$ deposits in the cerebellum of the infected CD1 mice were significantly less than the other two types of mice (Fig. 5).

Similar pathological changes noted in the brains of SMB-S15 infected mice. To study the neuropathological characteristics of infected mice, brain sections of the S15- and PS-inoculated C57BL/6, CD1 and Balb/c mice of the first passage were analyzed by H\&E staining, and GFAP- and Iba1-specific IHC tests. Numerous various-sized vacuoles were observed in the brain tissues of S15-inoculated mice, but not in those of PS-inoculated mice (Fig. 6). The majority of the vacuoles were round or oval and varied in terms of size. Generally, spongiform changes in the cortex were more obvious than those in the cerebellum. CD1 


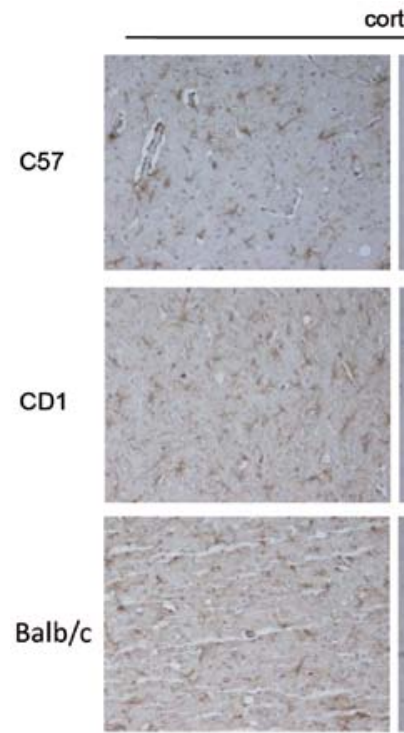

S15 cortex
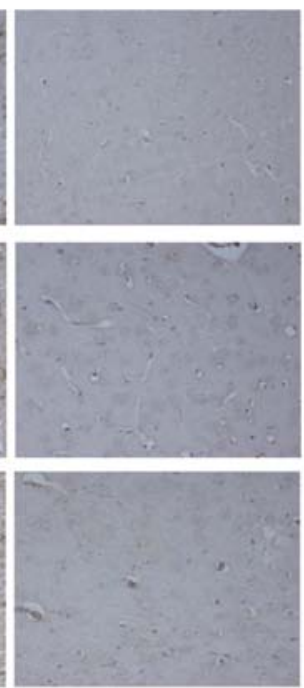

PS
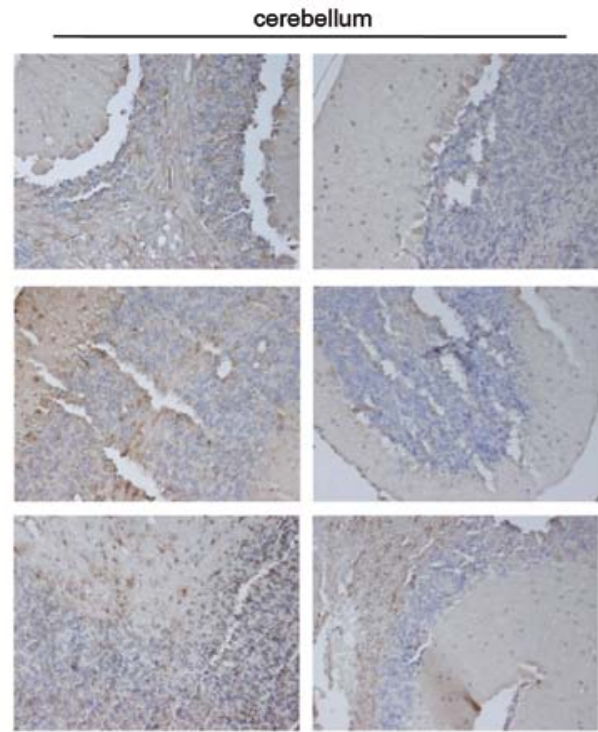

S15

Figure 7. Glial fibrillary acidic protein (GFAP)-specific immunohistochemical (IHC) assays of the brains of SMB-inoculated mice. Left panels, cortex; right panels, cerebellum; magnification, $\mathrm{x} 40$. Different strains of mice are indicated on the left.

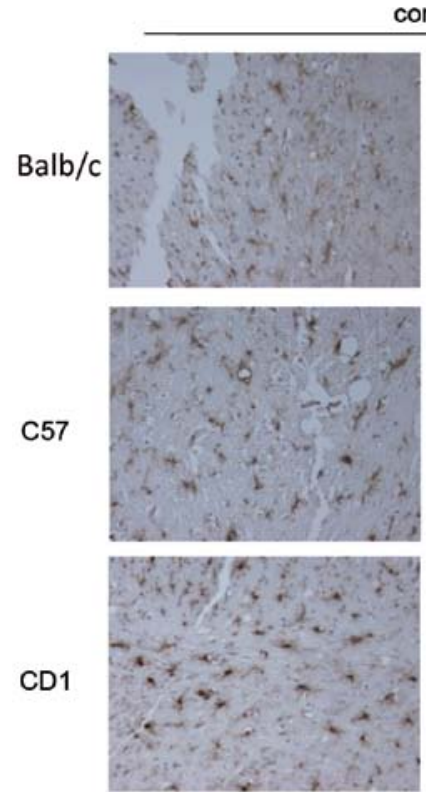

S15 cortex
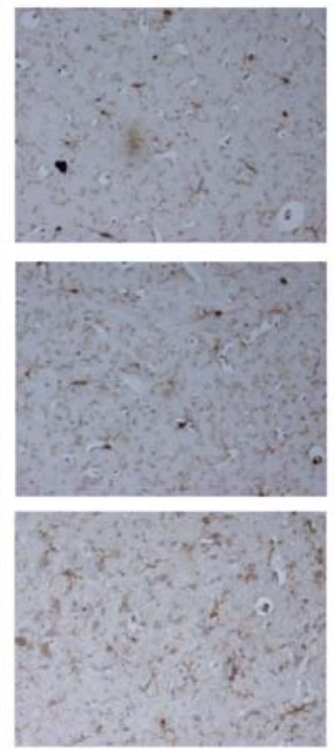

PS
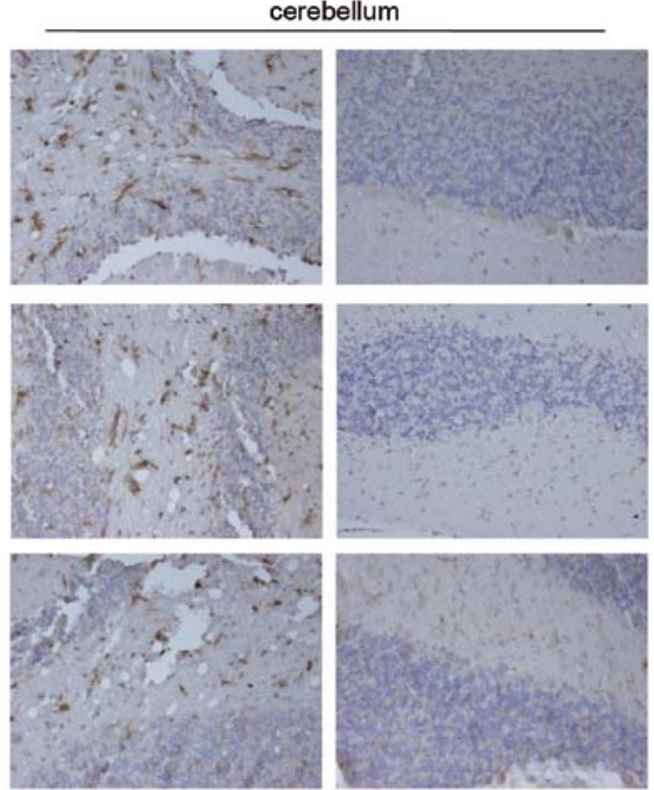

$\mathrm{S} 15$
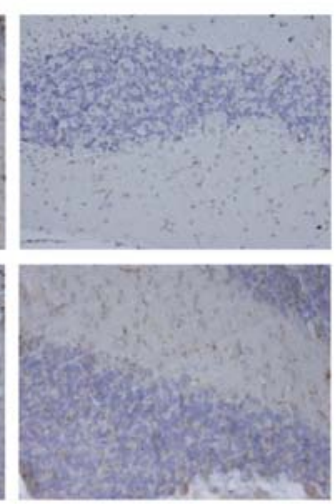

PS

Iba

$\times 40$

Figure 8. Iba-specific immunohistochemical (IHC) assays of the brains of SMB-inoculated mice. Left panels, cortex; right panels, cerebellum; magnification, $x 40$. Different strains of mice are indicated on the left.

mice seemed to have more and larger vacuoles than the other two groups of mice. Calculations of the severity and distribution of vacuoles in the cortex and cerebellum of the infected mice revealed that the average lesion scores in the cortex of C57BL/6, CD1 and Balb/c mice were 3.3, 3.7 and 3.0, respectively, while those in cerebellum were all 0.5. Abundant, large GFAP positive-stained astrocytes were noted in the brain tissues of all three strains of infected mice, and astrogliosis in the cortex region was more notable than that in cerebellum region (Fig. 7). Iba1-specific IHC assays identified abundances of microglia with much larger round- or amoeboid-shaped cell bodies in the sections of S15-infected mice, and no significant difference between the cortex and cerebellum was noted between the three strains of mice (Fig. 8). These data confirm that all three types of mice infected with SMB-S15 lysates exhibit typical neuropathological abnormalities representative of experimental TSEs 


\section{Discussion}

The SMB-S15 cell line was established originally using a culture from the brain of a mouse affected by the Chandler scrapie strain. This cell line consistently expresses $\mathrm{PrP}^{\mathrm{Sc}}$ during cell passage, whereas the SMB-PS cell line is an SMB-S15 cell line cured by PS, in which $\operatorname{PrP}^{\mathrm{Sc}}$ is completely removed. In the present study, we successfully set up three experimental scrapie infections with SMB-S15 cell lysates using three different phenotypic mice, C57BL/6, CD1 and Balb/c, respectively, and gained pathogenic and pathological confirmation. The infectivity of the brain homogenate of SMB-inoculated mice has been also confirmed in this study by successively inoculating three strains of mice. Moreover, the mice inoculated with the lysates of SMB-PS cells were all healthy, with no detectable abnormality in the brains. Thus, the findings of this study verify that the prion agent in SMB-S15 remains ineffective in experimental mice after long-term propagation in vitro.

Chandler is a commonly used scrapie strain, which was originally adapted using CD1 mice decades ago (21). The incubation time of strain Chandler via intracerebral inoculation is $166 \pm 5$ days (22). Coincidentally, in a previous study it was noted that three strains of mice infected with SMB-S15 lysates had similar incubation times, approximately 175 days in the first passage, highlighting again that the incubation time is strongly influenced by the original prion strain (23). Furthermore, as demonstrated in the present study, the incubation times of the second passages of all infected mice were shorter than the first passages. It has been previously observed, when the TSE agents are passaged in new, sensitive host species, that the incubation period will shorten during the first passage and become stable in the later passages (24). Although SMB cells are mouse neuron-derived cells, the relatively shorter incubation times of the second passages of S15-infected mice noted in the present study indicate that the scrapie agents propagating in the cultured cells in vitro need to adapt a little when replicating in the brain tissues of the same species in vivo. By contrast, our previous studies have verified that interspecies transmissions of mouse-adapted scrapie strains 139A and ME7 into hamsters require much longer incubation periods (395 days in 139A and 496 days in ME7), but the incubation times become much shorter in the successive passages (176 days in 139A and 183 days in ME7), which are comparable with that of their parent mouse strains, as noted in a previous study on C57BL/6 mice (Shi et al, unpublished data). Obviously, TSE agents need much longer times for adaption in different species hosts.

The main biochemical characteristics of $\mathrm{PrP}^{\mathrm{Sc}}$, such as the electrophoretic positions, the glycosylating patterns, $\mathrm{PK}$ resistance and the length of $\mathrm{C} 2$ fragments, in the brains of three strains of the infected mice are quite comparable. Furthermore, the neuropathological features, such as $\operatorname{PrP}^{\mathrm{Sc}}$ deposits, spongiform degeneration, reactive gliosis and activated microglia, are also similar in the three types of infected mice. However, the molecular profiles of $\mathrm{PrP}^{\mathrm{Sc}}$ and some neuropathological features change during interspecies transmission and were maintained stably afterwards (24). This implies that prions possess stable pathogenic and pathological features when they adapt in a particular species, regardless of whether they propagate in vivo or in vitro.
$\mathrm{CD} 1, \mathrm{C} 57 \mathrm{BL} / 6$ and Balb/c mice are distinct phenotypic animals, with different color body hair (white in CD1 and Balb/c, and black in C57BL/6) and body weight (CD1 mice are clearly larger than Balb/c and C57BL/6). However, the induced experimental scrapie in those mice, regardless of clinical or pathological aspects, is quite similar. In the present study, PRNP gene analysis verified the level of homogeneity between the three strains of mice, with only one nucleotide difference (C564T) in CD1 mice but a synonymous SNP. The polymorphisms of codon 128, corresponding to codon 129 in humans, of three types of mice are all Met/Met homozygote. The PRNP similarities in the three types of mice provide genetic support for the theory that there are similar phenotypes of experimental scrapie after inoculation with the same scrapie agent. On the other hand, our data in the present study also highlight that no other factor from the host side, except $P R N P$, influences susceptibility to prion infection.

In addition to severe loss of weight, extreme emaciation and sluggishness, that were commonly seen in all infected animals, ataxia and trembling were also frequently identified in the S15-inoculated C57BL/6 and Balb/c mice, but much less frequently in CD1 mice. Interestingly, the deposits of $\operatorname{PrP}^{\mathrm{Sc}}$ in the cerebellum of the infected CD1 mice were also significantly less than in the other two types of mice. As well as the difference in $\mathrm{PrP}^{\mathrm{Sc}}$ deposits in the cerebellum, other neuropathological abnormalities, including spongiform degeneration, gliosis and activated microglia, were also comparable between the three types of the infected mice. Thus, it seems that the fewer cerebellum-associated symptoms in CD1 mice are related to less deposition of $\mathrm{PrP}^{\mathrm{Sc}}$ in the cerebellum region. However, the exact mechanism for such diversity remains unknown. One may postulate that there are some slight differences in the brain microenvironments of those three strains of mice. High levels of microglia proliferation in S15-infected mice, which have been repeatedly observed in the brains of naturally occurring sporadic CJD (25) and experimentally scrapie-infected rodents (26), reflect the activation of the innate immune system during prion infection.

The electrophoresis and glycosylation patterns of $\mathrm{PrP}^{\mathrm{Sc}}$ are used as indexes for distinguishing prion strains (27). The brain $\mathrm{PrP}^{\mathrm{Sc}}$ levels from three different strains of S15-infected mice demonstrate the exact same electrophoretic and glycosylation profiles, and profile patterns have also been noted. The stable electrophoresis and glycosylation patterns of $\mathrm{PrP}^{\mathrm{Sc}}$ from brain to cultured cells (Chandler strain to SMB-S15 cells) and from cells to brain (SMB-S15 cells to S15-inoculated mice) supply strong molecular evidence for the maintenance of prion-strain characteristics during passage in the same biological species. Moreover, the $\mathrm{PrP}^{\mathrm{Sc}}$ molecules from three S15-infected mice reveal similar electrophoresis and glycosylation patterns as the $\operatorname{PrP}^{\mathrm{Sc}}$ molecules in the brains of two other mouse-adapted stains, 139A- and ME7-infected mice. In our previous study, it was proposed that the glycosylating profiles of $\mathrm{PrP}^{\mathrm{Sc}}$ are altered during interspecies transmissions of scrapie agents 139A and ME7 from mouse to hamster, generating hamster strain 263K-like patterns with predominate diglycosyl $\mathrm{PrP}^{\mathrm{Sc}}$ (28). Such changed glycosylating patterns are stably maintained during the subsequent passage in hamsters (Shi et al, unpublished data). The transitions of glycosylating patterns of $\mathrm{PrP}^{\mathrm{Sc}}$ molecules of mouse-adapted strain 139A and hamster-adapted strain $263 \mathrm{~K}$ 
have recently been observed in interspecies protein misfolding cyclic amplification (PMCA) (Gao et al, unpublished data). Taken together, our data suggest that as well as the prion strains, the host microenvironment, particularly host $\mathrm{PrP}^{\mathrm{C}}$, also contributes greatly to the molecular features of $\mathrm{PrP}^{\mathrm{Sc}}$.

In conclusion, we have successfully re-infected the prions of a prion-infected cell line into three different strains of mice. The majority of the clinical, pathogenic and pathological characteristics in three types of mice are similar. The $\mathrm{PrP}^{\mathrm{Sc}}$ deposits in the cerebellum region are different, an aspect possibly linked with the slight diversity in the cerebellumassociated symptoms. In addition, the present study provides us with more choices of scrapie rodent models which may be used in further studies.

\section{Acknowledgements}

The present study was supported by the Chinese National Natural Science Foundation Grants (no. 81301429 and 81572048), the China Mega-Project for Infectious Diseases (nos. 2011ZX10004-101 and 2012ZX10004215) and the SKLID Development Grant (nos. 2012SKLID102 and 2015SKLID503).

\section{References}

1. Liberski PP: Historical overview of prion diseases: a view from afar. Folia Neuropathol 50: 1-12, 2012.

2. Prusiner SB: Novel proteinaceous infectious particles cause scrapie. Science 216: 136-144, 1982.

3. Prusiner SB: The prion diseases. Brain Pathol 8: 499-513, 1998.

4. Caughey B, Race RE and Chesebro B: Detection of prion protein mRNA in normal and scrapie-infected tissues and cell lines. J Gen Virol 69: 711-716, 1988.

5. Chesebro B, Race R, Wehrly K, Nishio J, Bloom M, Lechner D, Bergstrom S, Robbins K, Mayer L, Keith JM, et al: Identification of scrapie prion protein-specific mRNA in scrapie-infected and uninfected brain. Nature 315: 331-333, 1985.

6. Bolton DC, McKinley MP and Prusiner SB: Molecular characteristics of the major scrapie prion protein. Biochemistry 23 5898-5906, 1984.

7. Meyer RK, McKinley MP, Bowman KA, Braunfeld MB, Barry RA and Prusiner SB: Separation and properties of cellular and scrapie prion proteins. Proc Natl Acad Sci USA 83: 2310-2314, 1986.

8. Stahl N, Baldwin MA, Teplow DB, Hood L, Gibson BW, Burlingame AL and Prusiner SB: Structural studies of the scrapie prion protein using mass spectrometry and amino acid sequencing. Biochemistry 32: 1991-2002, 1993.

9. Colby DW and Prusiner SB: Prions. Cold Spring Harb Perspect Biol 3: a006833, 2011

10. Dolby DW and SB P: Prions. Cold Harb Perspect Biol 3: a006833, 2011. doi: 10.1101/cshperspect.a006833.

11. Kretzschmar HA, Prusiner SB, Stowring LE and DeArmond SJ: Scrapie prion proteins are synthesized in neurons. Am J Pathol 122: 1-5, 1986.

12. McLennan NF, Rennison KA, Bell JE and Ironside JW: In situ hybridization analysis of PrP mRNA in human CNS tissues. Neuropathol Appl Neurobiol 27: 373-383, 2001.
13. Oesch B, Westaway D, Wälchli M, McKinley MP, Kent SB, Aebersold R, Barry RA, Tempst P, Teplow DB, Hood LE, et al: A cellular gene encodes scrapie PrP 27-30 protein. Cell 40: 735-746, 1985.

14. Race RE, Fadness LH and Chesebro B: Characterization of scrapie infection in mouse neuroblastoma cells. J Gen Virol 68: 1391-1399, 1987.

15. Butler DA, Scott MR, Bockman JM, Borchelt DR, Taraboulos A, Hsiao KK, Kingsbury DT and Prusiner SB: Scrapie-infected murine neuroblastoma cells produce protease-resistant prion proteins. J Virol 62: 1558-1564, 1988.

16. Birkett CR, Hennion RM, Bembridge DA, Clarke MC, Chree A, Bruce ME and Bostock CJ: Scrapie strains maintain biological phenotypes on propagation in a cell line in culture. EMBO J 20: 3351-3358, 2001.

17. Clarke MC and Haig DA: Multiplication of scrapie agent in cell culture. Res Vet Sci 11: 500-501, 1970.

18. Zhang J, Chen L, Zhang BY, Han J, Xiao XL, Tian HY, Li BL, Gao C, Gao JM, Zhou XB, et al: Comparison study on clinical and neuropathological characteristics of hamsters inoculated with scrapie strain $263 \mathrm{~K}$ in different challenging pathways. Biomed Environ Sci 17: 65-78, 2004.

19. Gao JM, Gao C, Han J, Zhou XB, Xiao XL, Zhang J, Chen L, Zhang BY, Hong T and Dong XP: Dynamic analyses of PrP and $\operatorname{PrP}(\mathrm{Sc})$ in brain tissues of golden hamsters infected with scrapie strain 263K revealed various PrP forms. Biomed Environ Sci 17: 8-20, 2004.

20. Deleault NR, Harris BT, Rees JR and Supattapone S: Formation of native prions from minimal components in vitro. Proc Natl Acad Sci USA 104: 9741-9746, 2007.

21. Chandler RL: Encephalopathy in mice produced by inoculation with scrapie brain material. Lancet 1: 1378-1379, 1961.

22. Moda F, Vimercati C, Campagnani I, Ruggerone M, Giaccone G, Morbin M, Zentilin L, Giacca M, Zucca I, Legname G and Tagliavini F: Brain delivery of AAV9 expressing an anti-PrP monovalent antibody delays prion disease in mice. Prion 6: 383-390, 2012.

23. Luers L, Bannach O, Stöhr J, Wördehoff MM, Wolff M, Nagel-Steger L, Riesner D, Willbold D and Birkmann E: Seeded fibrillation as molecular basis of the species barrier in human prion diseases. PLoS One 8: e72623, 2013.

24. Shi Q, Xiao K, Zhang BY, Zhang XM, Chen LN, Chen C, Gao C and Dong XP: Successive passaging of the scrapie strains, ME7-ha and 139A-ha, generated by the interspecies transmission of mouse-adapted strains into hamsters markedly shortens the incubation times, but maintains their molecular and pathological properties. Int J Mol Med 35: 1138-1146, 2015.

25. Shi Q, Xie WL, Zhang B, Chen LN, Xu Y, Wang K, Ren K, Zhang XM, Chen C, Zhang J and Dong XP: Brain microglia were activated in sporadic CJD but almost unchanged in fatal familial insomnia and G114V genetic CJD. Virol J 10: 216, 2013.

26. Xie WL, Shi Q, Zhang J, Zhang BY, Gong HS, Guo Y, Wang SB, $\mathrm{Xu} \mathrm{Y}$, Wang K, Chen $\mathrm{C}$, et al: Abnormal activation of microglia accompanied with disrupted CX3CR1/CX3CL1 pathway in the brains of the hamsters infected with scrapie agent $263 \mathrm{~K}$. J Mol Neurosci 51: 919-932, 2013.

27. Aguzzi A, Heikenwalder M and Polymenidou M: Insights into prion strains and neurotoxicity. Nat Rev Mol Cell Biol 8: 552-561, 2007.

28. Shi Q, Zhang BY, Gao C, Zhang J, Jiang HY, Chen C, Han J and Dong XP: Mouse-adapted scrapie strains 139A and ME7 overcome species barrier to induce experimental scrapie in hamsters and changed their pathogenic features. Virol J 9: 63, 2012. 